\title{
ZAPOMNIENIE BYCIA JAKO ZAGROŻENIE BYCIA WEDŁUG JEAN-YVES LACOSTE'A
}

\begin{abstract}
Streszczenie. Artykuł stawia tezę, że według Jean-Yves Lacoste’a zapomnienie bycia prowadzi do zagrożenia bycia. Problem zapomnienia bycia pojawia się we wczesnych dziełach Lacoste’a, jednak dopiero w książce Présence et parousie filozof po raz pierwszy przedstawia go szeroko w kontekście możliwości więcej niż egzystencji. Zwracając uwagę na fenomeny stanowiące aberrację w stosunku do bycia-w-świecie, takie jak: radość, nadzieja i liturgia, pokazuje, że bycie wykazuje nadmiar. Na tej podstawie autor niniejszego artykułu dochodzi do wniosku, że nadmiar bycia w stosunku do świata pokazuje, że nie ma w świecie nic, co przeczyłoby możliwości bycia-wobec-Boga. W książce Être en danger Jean-Yves Lacoste rozwija koncepcję zapomnienia bycia jako bycia-w-zagrożeniu. Na jej podstawie autor artykułu stawia tezę, że zapomnienie nie tyle zagraża byciu, co pokazuje, że bycie jest raczej niedostępne niż dostępne. Nadmiar niedostępnego w stosunku do dostępnego w byciu pokazuje, że nie ma w nim nic, co przeczyłoby możliwości pełni bycia. Na koniec autor stawia tezę, że pamięć o byciu otwiera możliwość ostatecznego, czyli eschatologicznego rozumienia bycia. Bycie jest wolą bycia, a nie tylko bycia po części. Dlatego możliwość pełni bycia jest wpisana w bycie i z konieczności się spełnia, prowadząc bycie do rozumienia siebie w kategoriach definitywnych, czyli eschatologicznych, a nie jedynie prowizorycznych. Pełnia bycia natomiast to Bóg. Dlatego bycie jest wolą bycia-wobec-Boga o wiele bardziej niż bycia-w-świecie.
\end{abstract}

Słowa kluczowe: bycie, fenomenologia francuska, filozofia religii, hermeneutyka bycia, hermeneutyka faktyczności, hermeneutyka liturgii

1. Wstęp. 2. Problem zapomnienia bycia w dziełach Jean-Yves Lacoste'a. 3. Zapomnienie bycia w kontekście więcej niż egzystencji - Présence et parousie. 4. Zapomnienie o byciu jako bycie-w-zagrożeniu - Être en danger. 5. Pamięć o byciu jako możliwość ostatecznego (eschatologicznego) rozumienia bycia.

\section{WSTĘP}

Jean-Yves Lacoste jest spadkobiercą tradycji tzw. zwrotu teologicznego $\mathrm{w}$ fenomenologii francuskiej. W związku $\mathrm{z}$ tym $\mathrm{w}$ swoich badaniach 
odnosi się często do osiągnięć fenomenologii Edmunda Husserla oraz do hermeneutyki egzystencji opracowanej przez Martina Heideggera. Tym samym zabiera również głos w kwestii zapomnienia bycia, podniesionej w Byciu i czasie. Zgodnie z sugestią zawartą w tytule niniejszego artykułu, zostaną tutaj poruszone dwa problemy: zapomnienia bycia oraz zagrożenia bycia. Pierwszy paragraf przedstawia krótko przegląd tych kwestii w różnych dziełach Jean-Yves Lacoste'a, ułożony chronologicznie w taki sposób, że pokazuje ewolucję podejścia filozofa do zagadnień zapomnienia bycia i zagrożenia bycia. Drugi paragraf omawia te problemy tak, jak zostały przez Lacoste'a opisane w eseju Plus qu'existence et être-en-danger z książki Présence et parousie. Jean-Yves Lacoste po raz pierwszy szeroko opisuje tam zagadnienia zapomnienia bycia i zagrożenia bycia oraz ich wzajemnego odniesienia. Tekst ten jest istotny dla zrozumienia jego podejścia do tych problemów i dlatego został tutaj poddany szczegółowej analizie. Trzeci paragraf pokazuje natomiast problemy zapomnienia bycia i zagrożenia bycia z perspektywy opisanej w książce $\hat{E} t r e$ en danger. Jean-Yves Lacoste rozwija w niej koncepcję zapomnienia bycia jako bycia-w-zagrożeniu. $\mathrm{Na}$ tej podstawie stawia tezę, że bycie jest poddane logice zagrożenia, ponieważ poddaje się logice nadmiaru. Oznacza to, że „być” zawsze oznacza więcej niż rozumieć bycie. Bycie pozostaje zatem raczej niedostępne niż dostępne poznaniu. Gra dostępności i niedostępności wpisana w bycie nie musi jednak stanowić dla niego zagrożenia. Dlatego w oparciu o tę tezę czwarty i ostatni paragraf przedstawia alternatywną wobec Jean-Yves Lacoste’a propozycję rozwiązania problemu relacji zapomnienia bycia i zagrożenia bycia. Pamięć o byciu rozważana jest tutaj nie jako zagrożenie, ale jako możliwość ostatecznego (eschatologicznego) rozumienia bycia. Rozwiązanie to okazuje się zarazem otwierać drogę do sformułowania argumentu na rzecz istnienia Boga. Warto zaznaczyć, że tezy zawarte w ostatnim paragrafie nie są tezami Jean-Yves Lacoste'a, choć zostały sformułowane w kontekście badań nad jego dziełami. 


\section{PROBLEM ZAPOMNIENIA BYCIA W DZIEŁACH JEAN-YVES LACOSTE'A}

Problem zapomnienia bycia pojawia się, choć jedynie w zarysie, jako poboczny w stosunku do głównego nurtu badań nad egzystencją, już w kontekście rozważań na temat czasowości zawartych w ściśle ze sobą powiązanych dwóch pierwszych dziełach Jean-Yves Lacoste'a: La emoire et l'espérance: Notes théologiques sur le temps z 1983 roku oraz Note sur le temps z 1990 roku, następnie jest kontynuowany w ramach rozważań nad topologią egzystencji w książce Expérience et absolu. Questions disputées sur l'bumanité de l'bomme z 1994 roku. Obok tych systematycznych wykładów swej myśli, Lacoste poruszał problem również w swoich esejach, które ukazały się w zbiorze Le monde et l'absence d'cuvre, et autres études w 2000 roku. Dopiero w książce Présence et parousie z 2006 roku, w rozdziale zatytułowanym Plus qu'existence et être-en-danger, przedstawia on po raz pierwszy swój pogląd na zapomnienie o byciu w kontekście koncepcji bycia zagrożonego, która pozostanie centralna dla jego późniejszych dzieł filozoficznych. Zbiór esejów La phénoménalité de dieu. Neufétudes z 2008 roku podnosi tę kwestię głównie w kontekście analiz husserlowskiej koncepcji poznania w eseju L'apparaitre et l'irreductible. Najszerzej problem zapomnienia o byciu porusza Jean-Yves Lacoste w książce zatytułowanej Etre en danger z 2011 roku, która stanowi podsumowanie wszystkich jego filozoficznych rozważań z okresu po Expérience et absolu. Widać tutaj wyraźną ewolucję w jego poglądach. Od koncepcji hermeneutyki egzystencji jako hermeneutyki liturgii przechodzi on do sformułowania koncepcji hermeneutyki bycia-w-zagrożeniu, wskazując zapomnienie bycia jako główne źródło owego zagrożenia. Podczas gdy hermeneutyka liturgii stanowiła raczej teologiczną interpretację egzystencji, koncepcja bycia-w-zagrożeniu stanowi jej reinterpretację pokazująca jej czysto filozoficzne implikacje. Problem przeplatania się wątków teologicznych i filozoficznych w swoich rozważaniach o byciu Jean-Yves Lacoste szerzej podejmuje i wyjaśnia w książce From theology to theological thinking, która ukazała się w Nowym Jorku w 2014 roku 
jako zapis wykładów wygłoszonych w ramach serii Richard Lectures 2010. W zbiorze esejów Jean-Yves Lacoste'a pt. L'intuition sacramentelle z 2015 roku problem pojawia się zdawkowo i nie wprost, ze względu na raczej teologiczny niż filozoficzny charakter rozważań. W książce Recherches sur la parole z $2015 \mathrm{r}$. temat zapomnienia i w związku z tym zagrożenia bycia zostaje niemal całkowicie pominięty. Natomiast $\mathrm{w}$ swojej najnowszej książce - Thèses sur le vrai z 2018r. - Lacoste powraca do niektórych tematów wcześniej poruszanych przy okazji rozważań nad problemem zapomnienia bycia, rozważa je jednak w kontekście zagadnienia zagrożenia dla prawdy, a nie dla bycia.

\section{ZAPOMNIENIE BYCIA W KONTEKŚCIE WIĘCEJ NIŻ EGZYSTENCJI - PRÉSENCE ET PAROUSIE}

Problem zapomnienia bycia Jean-Yves Lacoste omawia szeroko po raz pierwszy w eseju Plus qu'existence et être-en-danger w kontekście gry zapomnienia świata z zapomnieniem egzystencji. Zgadza się on z Martinem Heideggerem stwierdzając, że hermeneutyka faktyczności interpretuje życie przeżywane w cieniu śmierci ${ }^{1}$. Nie kwestionuje zatem skończoności egzystencji jako takiej, poddaje natomiast w wątpliwość ograniczenia, jakie nakłada na nią świat. Badając fenomeny, które w kontekście bycia-w-świecie wydają się jedynie aberracją, zadaje sobie pytanie o to, czy hermeneutyka egzystencji może prowadzić do zapomnienia świata oraz czy owe aberracje mogą być jakoś połączone z pełniejszą formą manifestacji faktu egzystencji².

Wśród wspomnianych aberracji wymienia: doświadczenie czystej radości bycia, doświadczenie nadziei, doświadczenia liturgiczne ${ }^{3}$. Zwraca uwagę na to, że te fenomeny są wprawdzie możliwe do zrozumienia, ale mimo to nie znajdują miejsca w ciasnych ramach

1 Por. J.-Y. Lacoste, Présence et parousie, Genewa 2006, 148.

2 Por. Tamże, 148.

3 Por. Tamże, 151. 
interpretacji egzystencji jako bycia-w-świecie. Świat rządzony jest przez fakt, a w ramach faktyczności nie ma miejsca dla fenomenów, które wykraczają poza wyznaczone przez śmiertelność granice skończoności. Jean-Yves Lacoste wybrał do swoich badań wspomniane trzy fenomeny, ponieważ każdy z nich jest przejawem zapomnienia faktyczności, a zatem również zapomnienia świata ograniczonego przez śmiertelność. Radość, nadzieja i liturgia to doświadczenia, w których bycie zapomina o tym, że nie zawsze i nie wszędzie może być. W tym kontekście analiza fenomenologii bycia z wcześniejszych dzieł Jean-Yves Lacoste’a prowadzi do wniosku, że takie zapomnienie o możliwości nie-bycia przypomina byciu o możliwości pełniejszego bycia. Wprawdzie on sam nigdzie nie formułuje wprost takiej tezy, choć nasuwa się ona jako konsekwencja jego fenomenologii zapomnienia bycia. Przypomina mu również, że egzystencja przekracza bycie-w-świecie, że egzystencja to nadmiar (l'excès), że egzystencja to również więcej niż egzystencja ${ }^{4}$. To, co Jean-Yves Lacoste w charakterystyczny dla siebie enigmatyczny i pełen niedopowiedzeń sposób nazywa więcej-niż-byciem lub dalej-niż-byciem, można w kontekście jego analiz egzystencji nazwać pełnią bycia. Okazuje się zatem, że koncepcja bycia-w-świecie z jednej strony opisuje faktyczność egzystencji, przypominając o tym, co dla niej najbardziej źródłowe, $z$ drugiej strony jednak stanowi zapomnienie egzystencji, wraz z wieloma ważnymi dla niej fenomenami, być może również zapomnienie tego, co dla niej najbardziej fundamentalne. W obliczu sytuacji zagrożenia bycie staje przed wyborem: albo niedobór manifestacji egzystencji w ramach świata, albo nadmiar manifestacji egzystencji sięgający dalej niż świat (au-delà-du-monde). Zapomnienie więcej-niż-bycia i zubożenie egzystencji do tego, co dostępne, czy też pamięć o więcej-niż-byciu i bezpośrednio niedostępny nadmiar egzystencji - oto dylematy, przed którymi stawia nas Lacoste ${ }^{5}$.

4 Por. Tamże.

5 Por. Tamże, 152. 
Jean-Yves Lacoste pokazuje, że zagrożenie bycia jest problemem, który pojawił się wraz z narodzinami badań nad byciem. Już Ja transcendentalne postulowane przez Edmunda Husserla stawiało badania nad byciem przed problemem monadyczności bycia. Bycie pojmowane jako monadyczne Ja jest w gruncie rzeczy byciem-w-zagrożeniu. Zagrożenie dotyczy nie tylko samego Ja, ale również rzeczy, świata, a wreszcie samej egzystencji. Ja pojmowane jako monada sprowadza, zdaniem Jean-Yves Lacoste'a, rzeczy do przedmiotów. Świat natomiast do zbioru przedmiotów albo do przestrzeni geometrycznej wypełnionej przedmiotami. Interpretacja świata zostaje sprowadzona do jego psychologizacji. Rozumienie egzystencji natomiast zostaje ograniczone do rozumienia reprezentacji oraz poręczności ${ }^{6}$, czyli do interpretacji podmiotu i jego ewentualnej ko-egzystencji z innymi podmiotami. Jean-Yves Lacoste określa tę sytuację mianem ulatniania się świata i egzystencji. Świat ulatnia się, a pozostaje po nim jedynie zbiór bytów albo ujednolicone pole ich ukazywania się. Po ulotnieniu się egzystencji natomiast zostają tylko świadomość i ręce ${ }^{7}$. Interpretacja monady nie jest interpretacją egzystencji, zatem dla hermeneutyki monady wszelkie fenomeny istotne $z$ punktu widzenia hermeneutyki bycia, takie jak troska lub radość, skończoność lub nadzieja, troska lub beztroska, tracą na znaczeniu. Zapomnienie o nieredukowalności bycia do monadycznego Ja jest dla niego zagrożeniem.

Według Lacoste'a przytoczone wcześniej trzy przykłady fenomenów: radość, nadzieja i liturgia, stanowią aberrację nie tyle w stosunku do koncepcji świata, ale w odniesieniu do koncepcji bycia jako bycia-w. Radość bycia jest stanięciem wobec bycia jako takiego, niejako wyjściem poza bycie, wzięciem w nawias ograniczenia narzuconego przez uwikłanie w bycie-w i cieszenie się byciem jako takim. Doświadczenie radości z bycia jako takiego przypomina eksperyment myślowy, który Lacoste przeprowadzał w swojej wcześniejszej

6 Por. Tamże, 153.

7 Por. Tamże. 
książce pt. Expérience et absolu. Questions disputées sur l'bumanité de l'homme ${ }^{8}$. Zastanawia się tam nad możliwością, choćby czysto teoretyczną, wyłączenia (l'exclusion) z bycia-w (être dans) na rzecz bycia-tam (être-là), czyli poza światem, które w konsekwencji jest również byciem-wobec (être vers) świata. Taka modyfikacja topologii egzystencji jest obrazem opisywanej przez Lacoste’a w późniejszej książce Présence et parousie radości z bycia - człowiek stawia się niejako poza uwikłaniem w jakikolwiek sposób bycia, by cieszyć się byciem jako takim. Bycie-w natomiast jest nieustannie zatroskane o siebie, ponieważ pozostaje ograniczone skończonością i zagrożone nie-byciem. Radość z bycia jako takiego jest fenomenem, który przeczy tej sytuacji albo zapomina o niej. Warto zwrócić uwagę na to, że zapomnienie o byciu-w jest jednocześnie przypominaniem sobie bycia. Podobnie nadzieja wynosi doświadczenie bycia dalej niż skończoność bycia-w, jest fenomenem przenoszącym doświadczenie na powierzchnię bycia 9 . Bycie-wobec-bycia jest jedynym sposobem przypominania sobie bycia. Bycie-w jest zawsze zapomnieniem o byciu. Bycie-w to bycie-w-zagrożeniu. Esse coram, être-face-à jest krokiem ku więcej niż egzystencji, wynurzeniem się na jej powierzchnię. Bycie-w jest zawsze bezpośrednio dostępne, bycie-wobec natomiast jest dostępne jedynie pośrednio, jako możliwość. Fenomeny radości, nadziei i liturgii otwierają się przed byciem jedynie jako możliwość wciąż niedostępnego spełnienia bycia, które jest zarazem spełnieniem radości, nadziei i liturgii. Czynią zrazem możliwym uzyskanie dostępu do owego nadmiaru egzystencji, który rozpościera się dalej niż świat. Nadmiar ten jest wprawdzie niedostępny sam w sobie, ale manifestuje się jako możliwość we wspomnianych aberracjach bycia-w. Przyjęcie przez bycie modusu bycia-wobec jako realnej możliwości, stanowi przypomnienie o byciu. W konsekwencji stanowi zarazem wyjście

8 Zob. Tenże, Expérience et absolu. Questions disputées sur l'humanité de l'homme, Paryż 1994, 28-31.

9 Por. Tenże, Présence et parousie, dz. cyt., 155. 
z prowizorycznego bycia-w-zagrożeniu ku możliwości definitywnego, a zatem ku możliwości spełnienia. Nie ma nic w byciu-w-świecie, co przeczyłoby możliwości bycia-wobec więcej niż egzystencji. Nie ma w byciu-w-świecie nic, co przeczyłoby możliwości bycia-wobec pełni bycia, czyli wobec Boga. Niedostępność Absolutu w świecie nie przeczy jeszcze jego możliwości, ze względu na nadmiar, jaki egzystencja przejawia wobec świata. Bycie z zasady jest raczej niedostępne niż dostępne, stąd cała opisywana tutaj gra pamięci i zapomnienia.

Jean-Yves Lacoste zwraca uwagę, że relacja wobec Absolutu otwiera w teraźniejszości możliwość szczęścia przypominającego ostateczne $^{10}$, a tym samym spełnienia wspomnianych wcześniej fenomenów radości, nadziei i liturgii, ponieważ zrywa ze zrównaniem egzystencji z byciem-w-świecie. W kontekście tego zerwania filozof wprowadza pojęcie życia, które jego zdaniem w pełniejszy sposób opisuje egzystencję, biorąc pod uwagę również to, co hermeneutyka faktyczności brała jedynie za aberrację, czyli fenomeny nie-źródłowe i nieautentyczne. Bycie-w-świecie klasyfikuje jako jeden ze sposobów życia, odmawiając mu zarazem roli arcyfenomenu (archiphénomène). Warto w tym kontekście wspomnieć, że Lacoste w swojej fenomenologii liturgii często gra francuskim pojęciem archiphénomène, używając go raz jako arcyfenomenu, czyli najbardziej fundamentalnego dla rozumienia bycia fenomenu, innym razem natomiast jako archifenomenu, czyli najbardziej pierwotnego fenomenu, w nawiązaniu do greckiego arché. Bycie-w-świecie jest dla Jean-Yves Lacoste’a jedynie początkiem doświadczenia i nie może pretendować do roli doświadczenia definitywnego, a zatem najbardziej fundamentalnego i pierwotnego. Dlatego nazywa je porankiem doświadczenia (le matin de l'expérience) ${ }^{11}$. Przypominanie bycia jest zatem dla Lacoste'a również przypominaniem życia, które stanowi wspólny wielu sposobom bycia fundament. Życie jednak, a nie jakikolwiek modus bycia, jest

10 Por. Tamże, 160.

11 Por. Tamże, 162. 
pierwszym fenomenem i pierwszym warunkiem fenomenalności, jest zatem bardziej pierwotne niż świat. Życie jest z jednej strony koniecznym substancjalnym umocowaniem egzystencji i bycia - zapewnia temu, co ontologiczne, oparcie w tym, co ontyczne. $Z$ drugiej strony natomiast wyraża nadmiar. Wchodząc w liturgię, życie wkracza w modus bycia, które Lacoste określa mianem „życia duchowego"12 stwierdzając, że jest ono wyrazem nadmiaru rozumienia w stosunku do świadomości. Lacoste podkreśla, że mówiąc o życiu duchowym nie próbuje tworzyć nowej koncepcji Ja, które można byłoby potem badać, podobnie jak kartezjańskie Cogito lub husserlowskie Ja transcendentalne ${ }^{13}$. Według niego duch (l'esprit) wprawdzie w jakieś mierze daje się świadomości, ale nigdy całkowicie się w niej nie manifestuje. Świadomość może opisać życie duchowe jedynie przez negację jako nie-miejsce, nie-wydarzenie, nie-doświadczenie. Duch (l'esprit) neguje tym samym absolutne panowanie świadomości nad doświadczeniem i sprowadza ją do roli narzędzia do badania poranka doświadczenia, zdolnego do poznania doświadczenia jedynie na bardzo ograniczonym podstawowym poziomie - sprowadza ją do roli narzędzia do badania tego, co prowizoryczne, bezradnego wobec tego, co definitywne. Dlatego zapomnienie o życiu, a zwłaszcza o życiu duchowym, na rzecz pojmowania egzystencji jako bycia-w-świecie, stanowi dla bycia zagrożenie.

Bycie-w tym, co prowizoryczne, rożni się od bycia-wobec tego, co definitywne, ale te dwa rodzaje bycia nie są od siebie oddzielone ${ }^{14}$. Granica między nimi natomiast przebiega we wnętrzu samego Ja, które zamieszkuje obszar granicy, na której przeplatają się te dwa sposoby bycia (zone de confins) ${ }^{15}$. Jak stwierdza Lacoste: „bycie-w-świecie i bycie-ponad-światem są faktami tego samego człowieka" ${ }^{16}$.

\footnotetext{
12 Por. Tamże, 162-164.

13 Por. Tamże, 165.

14 Por. Tamże, 166.

15 Por. Tamże, 166.

16 Tamże, 166.
} 
Dalej określa życie duchowe jako „doświadczenie paraegzystencjalne” (expérience paraexistentiale), ponieważ z jednej strony jest inne niż egzystencja, z drugiej jednak, mieszając się z egzystencją, pozostaje z nią ściśle powiązane. Najważniejsze jest tutaj to, że Lacoste przyznaje życiu duchowemu charakter wrodzony, zaliczając je do „naszego wrodzonego zbioru możliwości”17. Tym samym stwierdza, że możliwość bycia-ponad-światem, czyli bycia-wobec-Boga (coram Deo), wpisana jest w strukturę bycia. Dlatego też uprawnionym jest twierdzenie, że zapomnienie o tej możliwości stanowi zapomnienie o byciu.

\section{ZAPOMNIENIE O BYCIU JAKO BYCIE-W-ZAGROŻENIU - ÊTRE EN DANGER}

Jean-Yves Lacoste w książce Être en danger wskazuje na problem zapomnienia o byciu jako główne źródło zagrożenia bycia ${ }^{18}$. W tym kontekście podnosi dwie kwestie: zapominalności bycia oraz zapomnienia o byciu. $Z$ jednej strony zatem sama struktura bycia jest taka, że popada ono $\mathrm{w}$ jakimś stopniu $\mathrm{w}$ zapomnienie, $\mathrm{z}$ drugiej strony natomiast człowiek doświadcza go, jednocześnie je zapominając ${ }^{19}$.

Bycie nie daje się w doświadczeniu w sposób właściwy przedmiotom, ale zawsze transcenduje wszelkie sposoby postrzegania. W związku z tym nie mamy dostępu do rozumienia bycia w taki sam sposób, jak mamy dostęp do rozumienia przedmiotów lub wydarzeń. Dlatego bycie niejako ze swej natury pozwala się zapomnieć, ponieważ nigdy nie daje się człowiekowi jako takie, jak zwraca uwage Jean-Yves Lacoste ${ }^{20}$. Bycie pozwala się zapomnieć w trzech modalnościach: nadmiaru (l'excès), czasu (le temps) i niekompletności (l'inachèvement $)^{21}$.

\footnotetext{
17 Tamże, 166.

18 Por. Tenże, Être en danger, Paryż 2011, 344-345.

19 Por. Tamże, 344.

20 Por. Tamże, 348.

21 Por. Tamże, 352-353.
} 
Bycie wykracza dalej niż byt, innymi słowy: to, co ontologiczne, wykracza dalej niż to, co ontyczne. Nadmiar bycia w stosunku do bytu prowadzi zarówno do przypomnienia bycia, jak i do jego zapomnienia. Stanowi on dla bycia zarazem sytuację uprzywilejowaną, jak i kryjącą w sobie zagrożenie. $Z$ jednej strony bytowość odsłania bycie, z drugiej jednak je zakrywa. Jean-Yves Lacoste podkreśla, że bycie nie daje się poznać w ramach żadnej pełnej i ostatecznej ontofanii ('ontophanie) ${ }^{22}$. Nadmiar bycia w stosunku do bytu - a ściśle mówiąc: w stosunku do substancji - jest tak znaczący, że pełnia doświadczenia bycia pozostaje zawsze niedostępna. Bycie daje się poznać jedynie pośrednio, jako zapośredniczone $\mathrm{w}$ bytach, a dokładniej za pośrednictwem substancji. W związku $\mathrm{z}$ tym pamięć o byciu jako takim jest zapośredniczona w pamięci o sposobach bycia ujawniających się w poszczególnych substancjach, ponieważ tylko tak bycie daje się poznać. Zagrożenie nie zostaje usunięte - bycie wciąż pozostaje w znacznym stopniu zapomniane. Natomiast pamięć o byciu okazuje się nieustanną walką z zapomnieniem, o czym Lacoste wspominał już w Note sur le temps ${ }^{23}$. W Être et danger $\mathrm{z}$ kolei, opisując grę pamięci i zapomnienia, posługuje się obrazem zakrywania i odkrywania. Zwraca uwagę, że żaden byt ani całkowicie nie odsłania, ani całkowicie nie zasłania bycia. Bycie staje się dostępne między owym zakrywaniem a odkrywaniem zapośredniczonym w bytach. Zagrożenie natomiast polega tutaj na tym, że owa gra zakrywania i odkrywania bycia prowadzi do jego zapomnienia na dwa sposoby: albo do zapomnienia o byciu i skupienia się na substancji, albo na sprowadzeniu bycia jako takiego do tego czy innego sposobu bycia odsłaniającego się w tym czy innym bycie.

Zapomnienie bycia prowadzi do zagrożenia bycia w trzech znaczeniach: powoduje załamanie metafizyki obecności, co w konsekwencji prowadzi do odebrania bytom statusu bytów w pełnym tego słowa

22 Por. Tamże, 357-358.

23 Por. Tenże, Note sur le temps, dz.cyt., 144. 
znaczeniu, co skutkuje zamazaniem statusu bycia na rzecz sposobów bycia $^{24}$.

Problem rozumienia bycia jako obecności stanął u początku całego zagadnienia zapomnienia o byciu. Redukcja sensu bycia do obecności stanowi jeden $z$ podstawowych wymiarów zagrożenia bycia. Zapomnienie bycia, zdaniem Jean-Yves Lacoste'a, osiąga swoją kulminację $\mathrm{w}$ zapomnieniu historii spowodowanym przez przeakcentowanie roli tu i teraz w interpretacji rzeczywistości. Jakie jest zatem znaczenie faktu, że byt daje się poznaniu na sposób obecności w procesie rozumienia bycia. Koncepcja bycia-tu-oto wydaje się przecież w tym kontekście jedynie inną nazwą bycia pojętego jako obecność. Rodzi się pytanie o to, do jakiego stopnia możemy sobie pozwolić na redukcję bycia do tu i teraz, by nie zatracić jego rozumienia, by go nie zapomnieć. Zwłaszcza że historia bycia jako taka nie musi wcale wyjaśnić niczego szczególnego o nim samym. Jak mówi Jean-Yves Lacoste, Sokrates prawdopodobnie niewiele wniósłby do naszego obecnego rozumienia bycia, podobnie jak nasze własne wnuki niekoniecznie muszą coś do niego dodać ${ }^{25}$. Prawdziwy problem - jego zdaniem tkwi w samym sposobie, w jaki bycie daje się poznać. Zmusza to do myślenia bycia w kategoriach „bycia, które było”, „bycia, które jest”, i „bycia, które będzie”. Ta sytuacja człowieka stającego wobec problemu bycia wymusza na nim redukcję bycia nie tyle do bycia „tu-oto” lub do bycia obecnego, ale do bycia dostępnego. „Bycie = bycie dostępne" jest zdaniem Jean-Yves Lacoste'a tautologią uprawnioną. Wszystko ze względu na centralną dla rozumienia bycia rolę życia świadomości, które jest skupione na teraźniejszości/obecności, ponieważ samo jest jedynie teraz obecne.

Zdaniem Lacoste'a w konsekwencji byty przestają być bytami w pełnym tego słowa znaczeniu. Zwraca on uwagę, że choć wydarzenie i w związku z tym historia przynależą do tu-oto (il $y$ a), to

24 Por. Tenże, Être en danger, dz.cyt., 354-357.

25 Por. Tamże, 355-356. 
jednak ich status ontyczny jest trudny do sprecyzowania. Niejednoznaczność statusu ontycznego historii bycia stawia je w sytuacji zagrożenia. W związku z tym nie tylko zapomnienie o historii jest zapomnieniem o byciu, ale również pamięć o historii nie musi wcale prowadzić do pamięci o byciu. Zarówno wydarzenie, jak historia wystawiają bycie na zapomnienie. Lacoste rozwija ten problem analizując bytowość dwóch przykładowych bytów historycznych: działania (l'action) i wspomnienia (le souvenir). Problem $\mathrm{z}$ historią bycia polega jego zdaniem na tym, że nie jest ona w żadnym momencie w czasie bezpośrednio dostępna. Działanie toczy się wprawdzie w teraźniejszości, ale rozciągniętej w czasie, a zatem nieuchwytnej. $Z$ analiz Lacoste’a wynika, że teraźniejszość wymyka się świadomości, która posiada z nią jedynie relację pośrednią. Podobnie jest ze wspomnieniem, które daje wprawdzie dostęp do bytowości wydarzenia, ale jedynie w sposób zapośredniczony w bytowości działającego w przeszłości bytu. Bytowość samego wydarzenia nie jest nigdy bezpośrednio dostępna, wynika jedynie z zapośredniczenia w bytowości bytów uczestniczących w wydarzeniu. Zdaniem Lacoste'a, biorąc pod uwagę fakt, że czasowość jest horyzontem rozumienia bycia, byty czasowe powinny najwięcej mówić o byciu jako takim ${ }^{26}$. Jednak nie zawsze tak jest. Na poparcie tego stwierdzenia przytacza on przykład kamienia, który wprawdzie jest bytem czasowym, jednak o byciu nie jest zdolny niczego powiedzieć. Nieuchwytność bytowości wydarzenia, działania i wspomnienia stanowi - zdaniem Lacoste'a - odbicie niedostępności bycia $^{27}$. Okazuje się, że jedyna dostępna poznaniu bytowość to ta, którą da się sprowadzić do przedmiotu. Na płaszczyźnie ontycznej zatem substancja odnosi zwycięstwo nad czasowością - poznanie zawsze sprowadza się do poznania substancji, czasowość natomiast zawsze pozostaje zapośredniczona. Bycie zatem wydaje się wtórne wobec substancji. Bytowość wydarzeń, działań lub wspomnień,

26 Por. Tamże, 356.

27 Por. Tamże, 355-356. 
zdaniem Lacoste'a zakłada substancję, ale jej nie posiada ${ }^{28}$. Sytuacja ta potwierdza, że bycie wykracza dalej niż byt. W niesprowadzalności tego, co ontologiczne, do tego, co ontyczne, ujawnia się również kolejny raz różnica ontologiczna, którą Lacoste przyjmuje i rozwija w swoich rozważaniach nad zapomnieniem bycia.

Konsekwencją zapośredniczenia historii bycia w substancji jest, zdaniem Jean-Yves Lacoste'a, sprowadzenie rozważań nad byciem do badania sposobów bycia ${ }^{29}$. Sytuacja ta zamazuje sens bycia, sprowadzając go do sensów odsłanianych przez tzw. ontologie regionalne. Lacoste wymienia kilka przykładów takich ontologii sposobów bycia: ontologia wydarzenia, ontologia świadomości, ontologia natury itp $^{30}$. Bycie w takim stopniu przekracza ramy dyskusji nad bytem, że pojawia się w niej jedynie w wymiarze minimalnym. Problem bycia traci rolę głównego problemu metafizyki na rzecz problemu substancji i zostaje w ten sposób sprowadzony do roli gry słownej. Zdaniem Lacoste'a konsekwencją tej sytuacji jest alternatywa: byt albo bycie. $Z$ jednej strony bycie może wystawić się na zagrożenie, wycofując się z dyskusji nad ontologią i czyniąc tym samym miejsce dla bytu. $Z$ drugiej strony natomiast może zająć centralne miejsce jako główny problem, wystawiając tym samym na zagrożenie byt, który zostaje w ten sposób sprowadzony do roli minimalnej.

Podsumowując, należy stwierdzić za Lacostem, że bycie jest poddane logice zagrożenia, ponieważ poddaje się logice nadmiaru ${ }^{31}$. Bycie przekracza byt w stopniu, który sprawia, że zarówno w naiwnym oglądzie, jak i w prowadzonej z metodologiczną dokładnością redukcji fenomenologicznej pozostaje zapomniane lub przynajmniej ignorowane. Bycie jako takie nigdy się nie fenomenalizuje, jak stwierdza Lacoste ${ }^{32}$. Dlatego zapomnienie bycia nim stało się problemem

28 Por. Tamże, 356.

29 Por. Tamże.

30 Por. Tamże.

31 Por. Tamże, 344.

32 Por. Tamże, 354. 
teoretycznym poddanym pod dyskusję, było już częścią najbardziej elementarnego, codziennego doświadczenia. Zagrożenie bycia umyka postrzeżeniu, podobnie jak samo bycie. Człowiek otoczony jest mnóstwem bytów, które dają się wprawdzie poznać jako takie a nie inne sposoby bycia, ale nigdy nie odsłaniają bycia jako takiego. Redukcja fenomenologiczna może wprawdzie wydobyć wyraźniej struktury bycia i pomóc lepiej je rozumieć, nie daje jednak dostępu do pełni bycia - nie odsłania jego ostatecznego sensu ${ }^{33}$. W tym kontekście widać, że zagrożenie bycia wynika $\mathrm{z}$ jego nadmiaru $\mathrm{w}$ stosunku do bytu - bycie zapośredniczone jest wprawdzie w substancji, ale jednocześnie się w niej nie wyczerpuje. Rozumienie bytu nie jest jeszcze zrozumieniem bycia. Może być jedynie rozumieniem pewnych sposobów bycia. Bycie jednak nie jest sumą sposobów, w jakich realizuje się w bytach. Donacja przekracza dar, a czas przekracza fragmentaryczność teraźniejszości ${ }^{34}$. Bycie stanowi z jednej strony czynnik jednoczący nieskończoną wielość sposobów bycia, z drugiej strony jednak nieskończenie je przekracza ${ }^{35}$.

Zagrożenie zapomnieniem bycia, zdaniem Lacoste'a, prowadzi do uprzedmiotowienia bytu ${ }^{36}$. W konsekwencji pociąga za sobą zapomnienie człowieka i zapomnienie Boga, co skutkuje nihilizmem. Zapomnienie bycia nie jest zatem dla niego jedynie problemem teoretycznym, ale nową i niepożądaną sytuacją egzystencjalną. Jak stwierdza Lacoste, „bycie pozwalając się zapomnieć, stawia byt w zagrożeniu"37.

Zapomnienie o byciu sprowadza poznanie do poznania substancji, a zatem uprzedmiotawia wszystkie byty. W ten sposób cały proces poznawczy zostaje sprowadzony do znanej z klasycznej metafizyki relacji podmiot-przedmiot, która dla Lacoste’a stanowi niedopuszczalną

33 Por. Tamże, 345.

34 Por. Tamże, 346

35 Por. Tamże.

36 Por. Tamże, 348-349.

37 Tamże, 349. 
redukcję podmiotowości do podmiotu ${ }^{38}$. Zapomnienie bycia jest zapomnieniem o całym bogactwie afektywności oraz sposobów bycia, które zostają z procesu poznawczego wyeliminowane na rzecz jego matematyzacji i technicyzacji. W ten sposób podmiotowość człowieka zostaje zredukowana do wyabstrahowanego podmiotu, którego zadaniem jest percepcja przedmiotu zredukowanego do substancji.

W konsekwencji na podobnej zasadzie, zdaniem Lacoste'a, dochodzi do redukcji relacji międzyludzkich, które zostają pozbawione podmiotowości. Technicyzacja i matematyzacja relacji ze światem i z innymi prowadzi do fizykalizmu, który przekonuje, że prawa fizyki wyczerpują sens tych relacji. Jean-Yves Lacoste przyznaje wprawdzie, że nie sposób wykluczyć zapośredniczenia życia jako takiego, a zwłaszcza życia świadomości w przyrodzie (Lacoste nazywa to zapośredniczeniem w fizyce), jednak nie może ona pretendować do roli ostatecznej wykładni sensu bycia jako takiego ani relacji, które nawiązuje ze światem i $z$ innymi ${ }^{39}$.

W konsekwencji okazuje się, zdaniem Lacoste’a, że w świecie pojętym jako zbiór przedmiotów, których jedyna możliwa relacja do podmiotu oparta jest na prawach fizyki i matematyki, a zatem jest czysto techniczna, nie ma miejsca dla Boga. Bóg w takim świecie mógłby istnieć jedynie jako najwyższy z przedmiotów, pozostający jednak w relacji z podmiotem na tych samych zasadach jak każdy inny przedmiot. Bóg, który nie byłby uprzedmiotowiony - Bóg przekraczający ramy fizykalnej przedmiotowości w świecie rządzonym przez technikę, jest zdaniem Lacoste'a niemożliwy. Jak wielokrotnie zwracał on uwagę w swoich wcześniejszych pracach, zapomnienie bycia prowadzi zatem do zapomnienia więcej-niż-bycia, do zapomnienia pełni bycia, czyli do zapomnienia Absolutu. Jedyna forma dyskursu o Absolucie w tej epoce techniki, to dyskurs poetycko-literacki, który - podobnie jak bycie - ostatecznie skazany jest na zapomnienie.

38 Por. Tamże.

39 Por. Tamże, 350. 
Wraz z zapomnieniem bycia rozumienie doświadczenia jako takiego ulega erozji, w związku z czym dochodzi również do redukcji zdolności poznawczych. Zagrożenie bycia jest zarazem zagrożeniem bytującego, zatem rozciąga się na całość dostępnej rzeczywistości. To, co dostępne, jest zagrożone przez nadmiar tego, co niedostępne. Jest to najważniejsza konsekwencja rozważań Jean-Yves Lacoste’a nad zagrożeniem bycia przedstawionych w $\hat{E}$ tre en danger. Zagrożenie bycia sprowadza się do odkrycia fundamentalnej prawdy o rzeczywistości jako takiej: rzeczywistość jest raczej niedostępna niż dostępna. Bycie dane jest tylko jako bycie-tu-oto. Daje się poznać „tutaj” a nie gdzie indziej, tylko w określonym momencie w czasie swej historii i historii obserwatora. Daje się poznać „oto”, a zatem jedynie w tym konkretnym sposobie bycia, który odsłania się jako zapośredniczony w danej substancji. Jak zwracał uwagę Lacoste w Note sur le temps opisując zapomnienie o Bogu, pamięć nie jest po prostu świadomością czegoś lub wiedzą o czymś, ale walką z zapomnieniem ${ }^{40}$. Zagrożenie wynika $\mathrm{z}$ tego, że rzeczywistością o wiele bardziej rządzi logika nadmiaru niż logika umiaru poznawczego sceptycyzmu i redukcji. Życie toczy się w obszarze między wiedzą a niewiedzą, między dostępnością a niedostępnością, między pamięcią a zapomnieniem o byciu. Jean-Yves Lacoste w ten sposób podsumowuje swoje rozważania zawarte we wcześniejszych pracach, zwłaszcza związanych z hermeneutyką liturgii. Pokazuje, że rozważań nad byciem nie można ograniczyć do „tu-oto”. Sama możliwość więcej niż bycia „tu-oto” zmienia perspektywę poznawczą. Jedynym sposobem na to, aby nadmiar bycia z zagrożenia stał się dla poznania szansą, wydaje się odkryciem znaczenia tkwiącej w tym nadmiarze możliwości.

40 Por. Tenże, Note sur le temps, dz.cyt., 144. 


\section{PAMIĘĆ O BYCIU JAKO MOŻLIWOŚĆ OSTATECZNEGO (ESCHATOLOGICZNEGO) ROZUMIENIA BYCIA}

Pamięć o byciu pojęta jako proces przypominania bycia, czyli jako walka z jego zapomnieniem, z natury swojej zmierza do ostatecznego, a nie tylko częściowego rozumienia bycia. Zapomnienie stanowi dla bycia zagrożenie, z którego wyzwala się ono na drodze odzyskiwania pamięci. Bycie-w jest modusem bycia, w którym bycie jest zarazem zapominalne (oubliable), czyli poddające się zapomnieniu, jak i zapomniane (oublié), czyli ograniczone do faktyczności. Bycie-w-świecie jest zatem zarazem byciem-w-zapomnieniu i dlatego byciem-w-zagrożeniu. Pamięć o byciu zmienia je zarówno w wymiarze ontycznym, jak i ontologicznym, wyzwalając je z sytuacji zagrożenia. Zapomnienie o byciu sięga zatem znacznie głębiej niż przypuszczał Martin Heidegger, głębiej nawet niż sądzi Jean-Yves Lacoste. Polega ono nie tylko na zapomnieniu o nieredukowalności bycia do problemu obecności, nie tylko na nieredukowalności egzystencji do bycia-w-świecie, ale również na nieredukowalności możliwości bycia-wobec-Absolutu (czyli bycia-wobec-pełni-bycia) do możliwości wolnego wyboru takiego sposobu bycia przez człowieka.

Bycie jest wolą bycia, a nie wolą bycia po części, bycia prowizorycznego lub bycia ograniczonego. Wola bycia nie zna granic - bycie zwraca się ku byciu, co nie oznacza wcale zwrócenia Dasein ku sobie, ale ku pełni bycia. Pragnienie bycia prowizorycznego, skończonego, początkowego, nie byłoby pragnieniem bycia, ale pragnieniem prowizorycznego, skończonego i początkowego. Stanowiłoby raczej pragnienie świata niż bycia. Bycie samo w sobie natomiast daleko przekracza ciasne granice świata. Dasein pragnąc bycia nie pragnie siebie, ale bycia jako takiego, czyli zarazem pełni bycia. Bycie jest wolą bycia, która pozostaje równie nieograniczona jak bycie samo. Ponadto warto zwrócić uwagę na to, że Dasein, pragnąc być zawsze, pragnie być bardziej, być tym, kim jeszcze nie jest - pragnienie bycia jest pragnieniem bycia kimś więcej, a nie bycia mniej - pragnieniem 
usuwania zaległości, a nie jej poszerzania. Pragnienie bycia zawsze prowadzi dalej niż bycie - jest ruchem na zewnątrz, a nie ku wnętrzu - jest raczej niepokojem (l'inquiétude) pojętym jako niemożność ustania $\mathrm{w}$ dążeniu wynikająca $\mathrm{z}$ niedostępności spełnienia, niż zatroskaniem (le souci). Bycie nie spełnia się będąc bardziej sobą, ale będąc więcej niż sobą. Nie spełnia się bardziej zakorzeniając się $\mathrm{w}$ świat, ale wybiegając dalej niż świat. W związku z tym bycie nie staje wcale przed jakimś fundamentalnym wyborem: prowizoryczne albo definitywne, skończone albo nieskończone, początkowe albo ostateczne, śmierć albo życie, jak twierdzi Lacoste. Bycie z natury swojej jest byciem dla (être-pour) definitywnego, dla nieskończonego, dla ostatecznego, dla życia, dla bycia w pełni, dla bycia absolutnego. Dlatego bycie jest ostatecznie byciem dla Absolutu, ponieważ to Absolut jest pełnią bycia. Możliwość zwrócenia się ku Absolutowi, możliwość liturgii (jak nazwałby to Lacoste) nie jest zatem jedynie jedną z wielu stojących przed byciem możliwości, które może wybrać lub odrzucić, jak utrzymuje Jean-Yves Lacoste. Jest więcej niż możliwością: jest możliwością realną, czyli taką, która w istotny sposób zmienia jego status ontyczny i ontologiczny.

Odejście od rozumienia bycia jako obecności na rzecz rozumienia go jako manifestacji pozwala ująć bycie zarazem jako faktyczność bycia-w-świecie, jak i jako możliwość sięgania dalej niż świat. Zapomnienie o możliwości spełnienia bycia byłoby zarazem zapomnieniem o byciu. Dlatego zagrożenie bycia płynie z zapomnienia o możliwości więcej-niż-bycia. Możliwość w odniesieniu do bycia można rozumieć przez analogię do możności w stosunku do aktu w klasycznej filozofii, tak jak to, co ontologiczne, można rozumieć przez analogię do tego, co ontyczne ${ }^{41}$. Możliwość jest wyrazem nadmiaru bycia w stosunku do świata, nadmiaru definitywnego w stosunku do prowizorycznego. Wreszcie jest również wyrazem nadmiaru możliwości bycia w stosunku do niemożliwości bycia, czyli do skończoności, ontologicznej śmierci, kolapsu egzystencji. Odkrycie

41 Por. Tenże, Être en danger, dz. cyt., 344-345. 
owego nadmiaru jest zarazem odkryciem, że bycie-w-zagrożeniu jest synonimem bycia-w-świecie, ponieważ zagrożenie wpisane jest w prowizoryczność świata. Jedynie to, co definitywne, jest wolne od zagrożenia. To, co prowizoryczne, jest zarazem zawsze zagrożone. Definitywne stanowi nadmiar wobec prowizorycznego i obnaża tkwiące w nim zagrożenie, ale samo nie poddaje się zagrożeniu. To, co definitywne, jest wprawdzie jedynie możliwością i w związku z tym jako taka manifestuje się jedynie na właściwy sobie, kruchy (fragile) sposób. Należy jednak podkreślić, że wspomniana kruchość nie czyni jej możliwością niepewną. Wynika to z tego, że to, co definitywne, jest nie tylko jedną $\mathrm{z}$ wielu możliwości, które mogą, ale nie muszą się spełnić - jak błędnie twierdzi Jean-Yves Lacoste ale jest możliwością realną, czyli taką, która z konieczności zawsze się spełnia. Definitywne wpływa na rzeczywistość w sposób, który zmienia ją nie tylko ontologicznie, ale również ontycznie. Zmiana ta wprawdzie jest jedynie możliwością zmiany, ale ze względu na to, że możliwość ta nie może się nie spełnić, sama w sobie jest już realną zmianą. Wskazuje na to integralność bycia w jego strukturze: temporalizacja nie ogranicza się do przed, teraz i dalej w świecie. Bycie nie wyczerpuje się w świecie, ale dąży dalej. W związku z tym możliwa jest temporalizacja eschatologiczna, pojęta jako synteza prowizorycznego świata i definitywnego, manifestującego się jako możliwość. Ja prowizoryczne i Ja definitywne nie są różnymi Ja, ale kontynuacją tego samego Ja, ponieważ temporalizacja to nic innego, jak identyczność Ja wobec nieidentyczności przeszłości i przyszłości. Zmiana polegająca na przechodzeniu czasowości z tej właściwej światu ku czasowości spełnienia bycia, zwanej przez Lacoste’a wiecznością (l'éternité), dokonuje się nie jako przejście do jakiegoś innego Ja, ale jako przemiana we wnętrzu Ja. To samo Ja, które niegdyś było jedynie prowizorycznym, sięgając dalej niż bycie, staje się definitywnym. Jean-Yves Lacoste zwraca tym samym uwagę, że należy postawić znak równości między Ja transcendentalnym (Moi transcendetale), Dasein i postulowanym przez niego Ja wiecznym (Moi éternel). Wynikiem 
tego równania jest Ja eschatologiczne (Moi eschatologique), czyli takie, które pozostając wprawdzie ograniczone przez prowizoryczność, rozumie siebie w kontekście możliwości definitywnego. Rodzi się ono w wyniku wspomnianej temporalizacji eschatologicznej. Warto podkreślić, że nie ma tutaj mowy o czasowości ani o temporalizacji eschatycznej, równie niedostępnej jak sam eschaton (tj. jak samo ostateczne spełnienie bycia), ale eschatologicznej, czyli takiej, która rodzi się na granicy prowizorycznego i definitywnego. Rozumie ona prowizoryczne z perspektywy otwartej przez możliwość definitywnego, dlatego nazywam ją eschatologiczną.

Dlatego możliwości bycia-wobec-Absolutu (czyli bycia-wobec-pełni-bycia) niepodobna zredukować do możliwości wolnego wyboru takiego sposobu bycia przez człowieka, jak twierdzi Jean-Yves Lacoste. Nie jest to kwestia wolności Ja, ale samej struktury bycia. Jak widać z powyższych analiz, bycie wydarza się tak, że dąży do definitywnego, a nie do prowizorycznego - dąży do pełni bycia, a nie do skończoności bycia. Zapomnienie o pełni bycia jest zatem zarazem zapomnieniem o byciu i dlatego stanowi zagrożenie. Wynika ono z tego, że choć bycie nie może całkowicie o sobie zapomnieć, może zapomnieć o więcej niż byciu, więcej niż egzystencji, może zapomnieć o pełni bycia, czyli o Absolucie. Zapomnienie Boga jest zarazem zapomnieniem bycia i dlatego jest dla niego zagrożeniem.

\section{BIBLIOGRAFIA}

Lacoste J.-Y., Être en danger, Wyd. Cerf, Paryż 2011.

Lacoste J.-Y., Expérience et absolu. Questions disputées sur l'humanité de l'homme,

Wyd. Presses universitaires de France, Paryż 1994.

Lacoste J.-Y., From theology to theological thinking, thum. z fr. C. Hackett, Wyd.

University of Virginia Press, Nowy Jork 2014.

Lacoste J.-Y., La mémoire et l'espérance: Notes théologiques sur le temps, Wyd. Presses universitaires de France, Paryż 1983.

Lacoste J.-Y., La phénoménalité de dieu. Neufétudes, Wyd. Cerf, Paryż 2008. 
Lacoste J.-Y., Le monde et l'absence d'œuvre, et autres études, Wyd. Presses universitaires de France, Paryż 2000.

Lacoste J.-Y., L'intuition sacramentelle. Et autres essais, Wyd. Ad Solem, Paryż 2015. Lacoste J.-Y., Note sur le temps. Essai sur les raisons de la mémoire et de l'espérance, Wyd. Presses universitaires de France, Paryż 1990.

Lacoste J.-Y., Présence et parousie, Wyd. Ad Solem, Paryż 2006.

Lacoste J.-Y., Recherches sur la parole, Wyd. Louvain-la-Neuve: Editions de l'Institut supérieur de philosophie, Louvain 2015.

Lacoste J.-Y., Thèses sur le vrai, Wyd. Presses universitaires de France, Paryż 2018.

\title{
OBLIVION OF BEING AS DANGER TO BEING ACCORDING TO JEAN-YVES LACOSTE
}

\begin{abstract}
This paper argues that, according to Jean-Yves Lacoste, oblivion of being is danger to being. Although the issue of the oblivion of being appears in his early works, it was only in Présence et parousie that he fully developed his view in the context of the possibility of more than existence. Pointing out the phenomena which seem to be aberrations with respect to being-in-the-world, he concludes that there is an excess of being. This paper contends that the excess of being with respect to the world shows that there is nothing in the world that could contradict the possibility of being-towards-God. In Être en danger, Jean-Yves Lacoste develops the concept of the oblivion of being as being-in-danger. Contrary to Lacoste, this paper suggests that oblivion is not a threat to being. Instead, it shows that being is rather unavailable than available. The excess of the unavailable with respect to the available in being shows that there is nothing in being which could contradict the possibility of the fullness of being. Ultimately, the author argues that memory of being opens the possibility of the definitive or eschatological understanding of being. Being is the will of being. It is not the will of being to a certain extent, hence the will of being partially. Therefore, the possibility of the fullness of being is intrinsic to being and can be considered a principle which fulfils itself, providing being with a self-understanding that is definitive, hence eschatological, rather than provisional. Because God is the fullness of being, being in itself is the will of being-towards-God rather than the will of being-in-the-world.
\end{abstract}

Keywords: being, French phenomenology, hermeneutics of being, hermeneutics of facticity, hermeneutics of liturgy, philosophy of religion

\footnotetext{
Przemysław Zgórecki

przemyslawzgorecki@gmail.com

Uniwersytet Kardynała Stefana Wyszyńskiego w Warszawie, Instytut Filozofii

Wóycickiego 1/3, 01-938 Warszawa
}

DOI: $10.21697 /$ spch.2019.55.4.05 